Izabela Desperak

Uniwersytet Łódzki

\title{
Udział kobiet w sferze publicznej w transformującej się Polsce. Analiza „Gazety Wyborczej” z lat 1989 i 2009
}

Tekst jest prezentacją wyników części badań, obejmujących wybrane _ okresy między 1989 a 2009 rokiem. Celem badań była analiza obecności kobiet w mediach, i pośrednio w sferze publicznej, poprzez ich medialną reprezentację. Składały się one na szerszy projekt, stanowiący próbę zdiagnozowania kierunku hipotetycznej zmiany społecznej, polegającej między innymi na wzroście udziału kobiet $\mathrm{w}$ sferze publicznej jako jednym $\mathrm{z}$ aspektów transformacji społeczno-politycznej w Polsce. Projekt obejmował różne wymiary politycznej partycypacji kobiet ${ }^{1}$, tu przedstawię jedynie wyniki analiz treści wybranych przekazów medialnych.

Relacjonowane badania to analiza treści pierwszej strony „Gazety Wyborczej” („GW”) z lat 1989 oraz 2009. Wybór „GW” wynikał z tego, że to jedyna ogólnopolska gazeta, ukazująca się nieprzerwanie w wybranym okresie. Powstała ona w 1989 roku i jest pewnego rodzaju rówieśnicą polskiej transformacji, przez jakiś czas reprezentując środowisko jej twórców i symbolizując przemianę. Mając największy nakład spośród gazet codziennych, wpisuje się w dyskurs mediów głównonurtowych. Utożsamiana jest jednocześnie z dyskursem modernizacyjnym i liberalnym, na jej łamach warto więc szukać ewentualnej zmiany miejsca kobiet w społeczeństwie.

Do prezentowanej części badań wybrałam dwa półrocza 1989 i 2009 roku (od 1 lipca do 31 grudnia, gdyż „GW” powstała w maju 1989 roku). Rok 2009 - dwudziestolecia transformacji - wybrałam, by móc porównać wydania odległe od siebie i obejmujące skrajne lata transformacji. Badanie objęło wyłącznie strony tytułowe gazety jako te, na których umieszcza się informacje o najwyższej randze, priorytetowe, kluczowe i kształtujące hierarchię ważności tematów w dyskursie publicznym. Analizie poddane zostały: tytuły artykułów, ilustracje, płeć autorów i redaktorów oraz zawartość treściowa

${ }^{1}$ Zob.: Izabela Desperak, Płeć w kampaniach wyborczych 20oo-2011, „Władza Sądzenia” 2013, nr 1; dostępne przez: http://wladzasadzenia.pl/2012/1/o5-plec-w-kampaniach-wyborczych.pdf (17.03.2013). 
wszystkich informacji. Porównano liczbę kobiet i mężczyzn, zarówno jako bohaterów, jak i nadawców komunikatów. Zanalizowano również pod względem jakościowym sposoby prezentacji kobiet i kwestii płci.

Skupienie się na pierwszej stronie dziennika pozwoliło ustalić, co stanowiło priorytet w obszarze hierarchii ważności (agenda setting), wartości oraz relacji redakcji gazety. Przeprowadzona analiza treści wykazała ogromną dysproporcję między kobietami i mężczyznami jako bohaterami newsów, tytułów i fotografii, także autorami i redaktorami, oraz minimalną obecność kwestii związanych z płcią. Przedstawiana jako nieposiadająca płci tematyka reprezentowana była przez mężczyzn - pierwszoplanowane postacie, bohaterów i sprawców wydarzeń. Kobiety na pierwszych stronach „GW" występowały dużo rzadziej, choć w badanym okresie nastąpiła zmiana i zmniejszenie się skali dysproporcji. Poszerzył się też repertuar kobiecych ról, jednak nie doszło do znaczącej zmiany w sposobie prezentacji kobiet i mężczyzn.

Tab. 1. Procentowy udział kobiet w zawartości pierwszych stron „Gazety Wyborczej” w latach 1989 i 2009

\begin{tabular}{|c|c|c|c|}
\hline $\begin{array}{c}\text { Rodzaj } \\
\text { zawartości }\end{array}$ & $\begin{array}{c}\text { Udział kobiet } \\
\text { w wydaniach } \\
\text { z 1989 roku (proc.) }\end{array}$ & $\begin{array}{c}\text { Udział kobiet } \\
\text { w wydaniach } \\
\text { z 2009 roku } \\
\text { - zawartość } \\
\text { pierwszego rzędu } \\
\text { (proc.) }\end{array}$ & $\begin{array}{c}\text { Udział kobiet } \\
\text { w wydaniach } \\
\text { z 2009 roku - } \\
\text { całość zawartości } \\
\text { pierwszej strony } \\
\text { (proc.) }\end{array}$ \\
\hline Tytuły & 2 & 21,1 & 20,9 \\
\hline $\begin{array}{c}\text { Ilustracje } \\
\text { (fotografie lub } \\
\text { rysunki) }\end{array}$ & 8,4 & 19,0 & 19,8 \\
\hline Teksty & 6,8 & 16,5 & 16,6 \\
\hline $\begin{array}{c}\text { Autorzy } \\
\text { tekstów }\end{array}$ & 17,7 & 30,6 & 24,2 \\
\hline
\end{tabular}

Źródto: badania wtasne.

Porównanie udziału kobiet w latach 1989 i 2009 ilustruje powyższa tabela. Dane dla roku 2009 zestawione zostały dwukrotnie ze względu na różnice wynikające z przyjętych metodologii. Kolumna trzecia tabeli zawiera wyłącznie dane dotyczące treści, które mogą być porównywane z tymi z 1989 roku: artykułów i ich ilustracji, notatek i komentarzy. „GW” z 2009 roku była zupełnie innym medium niż ta wydawana 20 lat wcześniej. Na pierwszej stronie, obok treści informacyjnych, znaleźć można było też reklamy, zapowiedzi zawartości dalszej części numeru, informacje o zawartości dodatków tematycznych czy dołączonych do wydania papierowego insertów, zwłaszcza 
płyt. Analiza prowadzona była dwutorowo: osobno dla treści, które występowały w obu badanych odcinkach czasu („zawartość pierwszego rzędu”) oraz osobno dla wszystkich treści, jakie znalazły się na pierwszej stronie badanej gazety w 2009 roku (całość zawartości pierwszej strony). Porównanie wyników badania zrealizowanego według obu metod dowiodło, że niezależnie od ich wyboru rezultaty były podobne - prawidłowość ta jest też pewnego rodzaju wnioskiem z badania, zamieszczam więc obie grupy danych, choć dla porównania lat 1989 i 2009 nie jest to niezbędne.

Porównanie liczby kobiet i mężczyzn na pierwszych stronach „GW” z jednej strony zwraca uwagę na dziesięciokrotny w zrost ilości kobiet $\mathrm{w}$ tytuła ch oraz ponad dwukrotny wzrost autorek. Wzrost liczby kobiet wymienionych w tytułach jest największy. Czy oznacza to wyraźną tendencję do zwiększenia udziału kobiet, czy też jest efektem innych zjawisk? Gdyby była to stała tendencja, można byłoby oczekiwać powolnego wzrostu i w roku 2029 czterdziestoprocentowego udziału kobiet w tytułach na pierwszej stronie. $\mathrm{Z}$ drugiej strony, efekt ten może mieć związek z doborem materiału badawczego. Wybrane półrocze 1989 roku stanowi wczesną fazę rozwoju gazety, która ewoluowała z wydawnictwa wyborczego: liczyła kilka stron, nie miała dodatków, początkowo nie wychodziła we wszystkie dni tygodnia a jej treść przyporządkowana była politycznemu celowi. Gazeta z 2009 roku to już po prostu dziennik, który rządzi się medialnymi, a nie politycznymi, priorytetami. Pomijanie roli kobiet w tytułach z 1989 roku wynikać może z kształtującej się wówczas hierarchii, może też oznaczać coś przeciwnego - początek wykluczania kobiet i pozbawiania ich politycznego znaczenia. Towarzyszące temu zjawisku, samowykluczanie się kobiet z pamięci Solidarności opisała na początku XXI wieku Shana Penn w Podziemiu kobiet ${ }^{2}$. Odzwierciedlają je tytuły „GW” z 1989 roku, wymieniające mężczyzn, a nie, przechodzące na marginalne wówczas pozycje, kobiety. Powodem takiego stanu rzeczy mogła być struktura budowy hierarchii postaci kształtująca się w redakcji „GW”, a odziedziczona po wydawnictwach opozycyjnych, która zepchnęła kobiety na dalsze pozycje. Ewentualnie, dysproporcje płci na pierwszej stronie „GW” odzwierciedlały ówczesne standardy prasowe, rodem z PRL-u. Aby odpowiedzieć na te pytania, należałoby przebadać inne roczniki „GW”, z lat pośrednich, lub prasę z okresu przełomu, na co nie było miejsca w relacjonowanym projekcie, obejmującym jedynie wybrane do analizy półrocza lat 1989 i 2009.

Wprawdzie udział kobiet wśród bohaterów na pierwszej stronie wzrósł niemal dziesięciokrotnie, to w 2009 roku kobiety stanowiły wciąż jedynie 20 proc. wymienionych postaci. Zmiana ilościowa, choć niebagatelna, nie

${ }^{2}$ Shana Penn, Podziemie kobiet, przeł. Hanna Jankowska, Rosner i Wspólnicy, Warszawa 2003. 
przynosi znaczącego przewartościowania: mężczyźni wciąż stanowią większość bohaterów. Za to zaobserwować można wyraźną zmianę jakościową - rozszerzenie wachlarza ról społecznych, w których kobiety są przedstawiane. W analizowanych 153 wydaniach „Gazety Wyborczej” z 2009 roku w 39 przypadkach na pierwszej stronie nie ma jakiejkolwiek wzmi anki o kobietach, z wyjątkiem nazwiska redaktorki prowadzącej. $\mathrm{W}$ pozostałych wydaniach kobiety były wymieniane w 16,5 proc. tekstów pierwszego rzędu i 16,6 proc. ogółu tekstów.

$\mathrm{W}$ ilustracjach, mimo liczbowego wzrostu udziału kobiet, nie widać większych zmian jakościowych. Kobiety najczęściej przedstawiane są w roli „dekoracji”, towarzyszek swych mężów, ofiar przemocy, żałobnic lub uczestniczek pogrzebów i bohaterek karykatur. Trudno ocenić, czy powtórzenie karykatury sprzedawczyni z 1989 roku w roku 2009 było zamierzone, ale trafnie symbolizuje trwałość schematu roli kobiety w ilustracji na pierwszej stronie „GW” (rys. 1). Obok karykatury sprzedawczyni ,jak z PRL-u” pojawiła się jednak w roku 2009 nowa karykatura - kobiety w postawie Napoleona, z ręką założoną za połę surduta (rys. 2). Stanowiła ona ilustrację postulatu Kongresu Kobiet dotyczącego parytetu płci na listach wyborczych. W analizowanych wydaniach na pierwszą stronę dziennika trafiały też fotografie odnoszących sukcesy sportsmenek i gwiazd estrady.

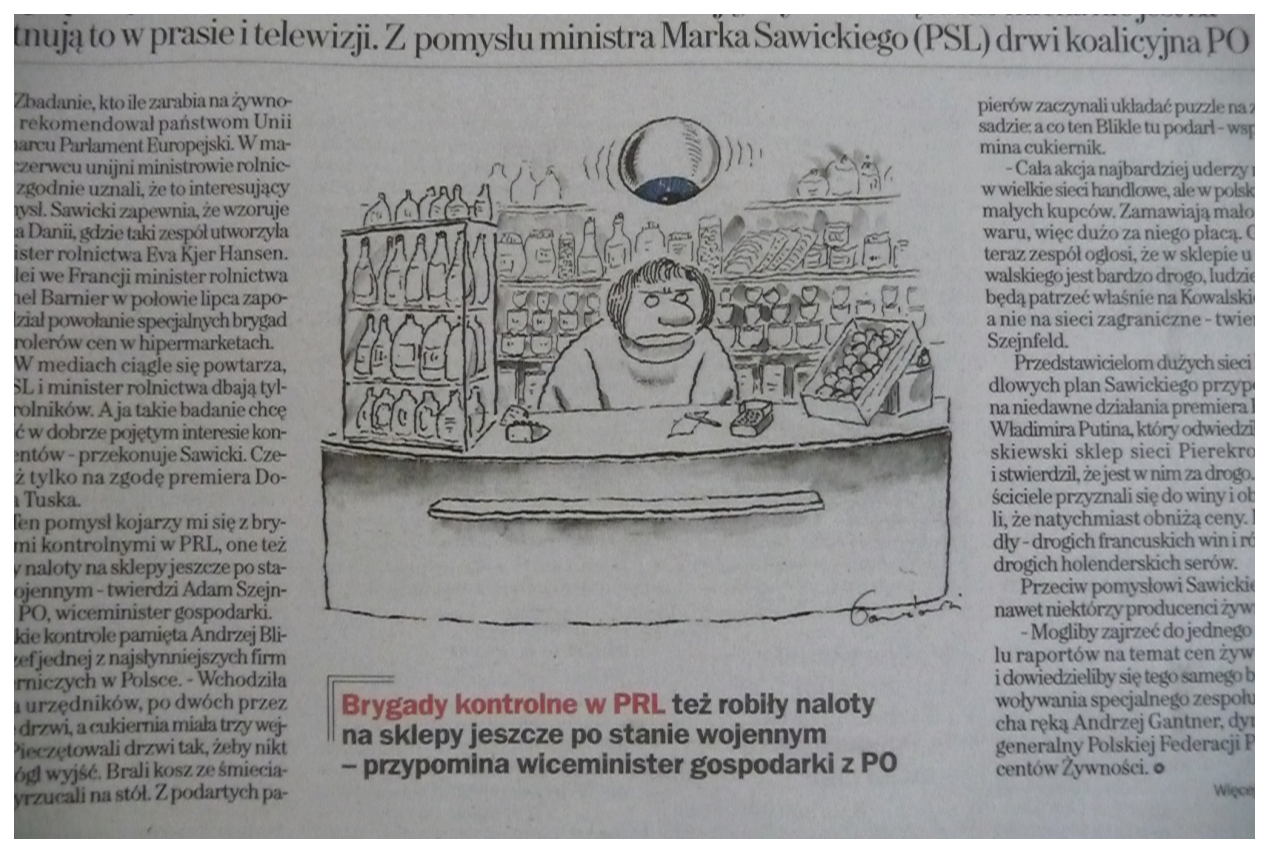

Rys. 1. Ilustracja Jacka Gawłowskiego, przywołująca stereotyp peerelowskiej sprzedawczyni („Gazeta Wyborcza” 22-23 sierpnia 2009) 


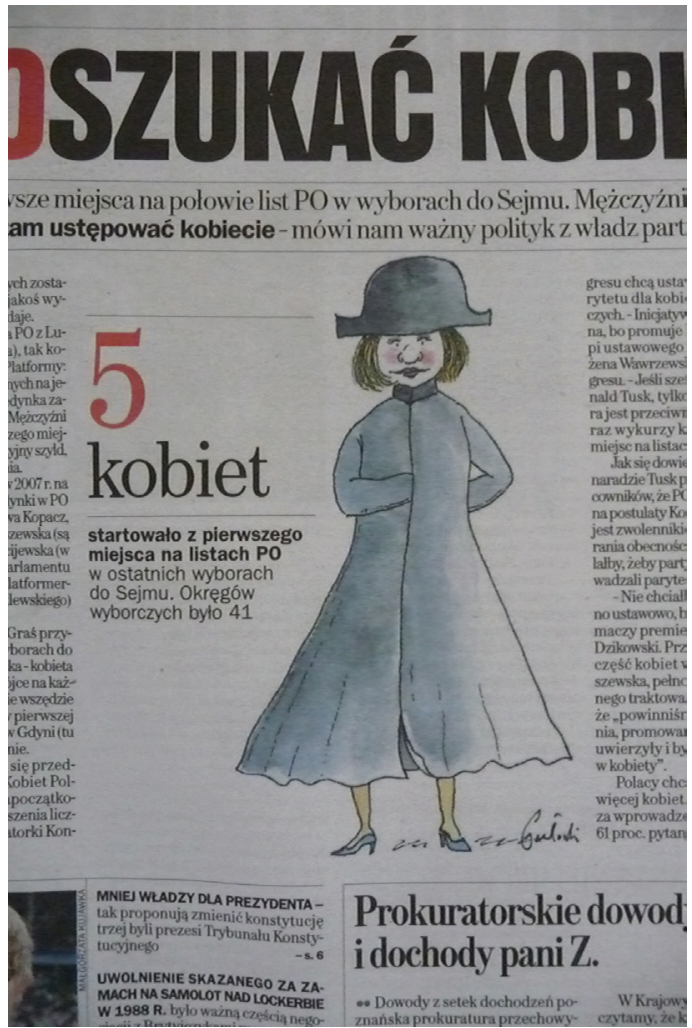

Rys. 2. Ilustracja do tekstu poświęconego parytetom („Gazeta Wyborcza” 25 sierpnia 2009)

W zawartości newsów z 2009 roku zwraca uwagę poszerzenie repertuaru kobiecych ról, co wydaje się automatyczną konsekwencją zwiększenia liczby przywołanych kobiet. Polityczki polskie i zagraniczne są przedstawiane z podobną częstotliwością w 1989 i 2009 roku. Kilkakrotnie częściej pojawiają się w 2009 roku ekspertki i szefowe. Nową kategorię stanowią dziennikarki czy pracowniczki nauki, a także działaczki i feministki. Po raz pierwszy mowa jest też o lesbijkach i kobietach nieheteroseksualnych oraz ofiarach zakazu aborcji w Polsce.

Tym, co łączy bohaterki pierwszych stron „GW” z 1989 i 2009 roku jest marginalność, występowanie w roli biernych przedmiotów działań reżyserowanych przez kogoś innego. Kobiety są ofiarami, rzadko sprawcami, przemocy. Inaczej niż mężczyźni, często występują anonimowo, pozbawiane są imienia i nazwiska. Dotyczy to i żony króla, i kobiety, która występowała najpierw jako anonimowa matka trójki dzieci, a jej imię i nazwisko pojawiły się dopiero po jakimś czasie i podane zostały jako część zwrotu „sprawa 
Wioletty Woźnej”3. Niezależnie od roli w jakiej występują, kobiety częściej są jedynie dodatkiem do treści newsa niż jego autonomicznymi bohaterkami. Imię lub jego brak, wiek, czasem wizerunek kobiety służą do wzmocnienia efektu dziennikarskiego i wywołania emocji u czytelników; kobiety przedstawiane są albo w roli wyciskających łzy ofiar, albo roztaczających urok dekoracji. Nawet ilustracje przestawiające kobiety ze sfery polityki, włącznie z przywódczyniami, estetyzują je. Zwraca uwagę częste pojawianie się kobiet - w tekstach i na ilustracjach - w kontekście śmierci. Wiele z nich na pierwszą stronę „GW” trafiło dopiero po śmierci: z okazji pogrzebu (jak Barbara Skarga), z okazji śmierci męża (jak wdowy po zabitych żołnierzach czy córka Leszka Kołakowskiego) lub jako ofiary tragicznych wydarzeń (jak martwe dziewczynki, ofiary serii zamachów w Bagdadzie).

Obok miejsca, jakie zajmują kobiety, przyjrzano się również tematom związanym z kobietami lub kwestią płci. Kobiety wymienione na pierwszej stronie „GW” w 1989 roku częściej reprezentowały ogół społeczeństwa niż były przedstawiane w kontekście spraw czy praw samych kobiet. Tematyka kobieca czy kwestia płci pojawiała się dużo rzadziej niż same kobiety. Dwa tematy dotyczące kobiet powracać będą w kolejnych latach i wyznaczać zakres tematyki kobiecej, tj. udział kobiet w polityce i zakaz przerywania ciąży.

W wydaniu z 24 sierpnia 1989 roku czytamy, że „entuzjazm wywołała odpowiedź [Tadeusza Mazowieckiego w przeddzień wyboru na premiera I.D.] na pytanie o rolę kobiet w przyszłym rządzie: myślę, że aby zmienić obraz społeczny rzecznika rządu trzeba będzie na to stanowisko mianować kobietę", co rzeczywiście później nastąpiło. Już jako premier Mazowiecki wypowiada się (25-27 sierpnia 1989 roku) na temat aborcji: „«jako katolik i człowiek walczący od lat z państwem światopoglądowym nie chcę zmieniać jednej koncepcji na drugą». Zapytany o podejście, jako premier, do problemu aborcji odpowiedział, że jest zwolennikiem ochrony życia, ale przeciwnikiem uciekania się w tej sprawie do rozwiązań represyjnych" - napisał w relacji z konferencji prasowej premiera Roman Kurkiewicz („GW” z 25-27 sierpnia 1989 roku).

Poza tym sygnałem o wzrastającej politycznej roli projektowanego zakazu przerywania ciąży, na tematykę kobiecą, poruszaną na pierwszej stronie „GW” składały się: zagadnienia pracy kobiet, strajk włókniarek, restrykcyjne prawo (aborcyjne) w Rumunii i wybory Miss Świata. Z nielicznymi wyjątkami, problematyka kobieca nie była więc treścią priorytetowych newsów pierwszego demokratycznego medium w transformującej się Polsce.

${ }^{3}$ Historia Wioletty Woźnej jest niezwykle znamienna, ponieważ sposób, w jaki opisywana była jej bohaterka w mediach ciekawie ewoluował. Początkowo kobietę określano jedynie jako matkę małej Róży, nieco później zaczęto jednak podawać jej imię i inicjał nazwiska, aby wkrótce przejść do pełnego nazwiska. Ostatecznie zaś używano nowego nazwiska kobiety, które przyjęła po wstąpieniu w związek małżeński z ojcem dziecka. 
Zjawisko to można interpretować dwojako: albo w kluczu uniwersalistycznym (kobiety i mężczyźni to współobywatele, uczestnicy opisywanych wydarzeń i odbiorcy treści), albo w kluczu dyskryminacyjnym (wykluczanie kobiet i ich spraw już na starcie). Rewolucja Solidarności w pamięci zbiorowej stała się męską sprawą, być może za taką uważali ją już wtedy jej współtwórcy i współtwórczynie.

Ze względu na rolę, jaką pełnić będzie wkrótce projekt zakazu aborcji i towarzyszący mu dyskurs ${ }^{4}$, warto zwrócić uwagę, że w 1989 roku zakaz aborcji przedstawiany jest jako restrykcyjne prawo totalitarnego reżimu Nicolae Ceauşescu, a jego zniesienie jako przejaw demokratyzacji. W Polsce tego okresu nawołuje się jedynie do ochrony życia, nic nie zapowiada zmiany w dyskursie, której skutkiem będzie wygranie wojny o język przez dyskurs anti-choice. Już kilka lat później zakaz aborcji, wprowadzony w Polsce w 1993 roku, nie jest przedstawiany w dyskursie głównego nurtu ani jako restrykcyjny, ani kojarzony z totalitarnym reżimem. W 1989 roku w „GW” obserwujemy dyskurs, którym po 1993 roku przemawiać będą wyłącznie nieliczne środowiska kobiece i feministyczne niegodzące się z zakazem.

Dwadzieścia lat później kwestia płci, dyskryminacji i jej przeciwdziałania stały się tematami politycznymi, choćby na skutek wejścia Polski do Unii Europejskiej (2004). Tematy związane z problematyką kobiecą i równościową poruszane na pierwszych stronach „GW” w 2009 roku to: Kongres Kobiet, aborcja, parytety płci, „wdowi grosz”, płeć kandydatek w wyborach (parytety), sterylizacja Wioletty Woźnej, zapłodnienie in vitro, równowaga płci na szczytach UE, „becikowe”6 i wiek emerytalny kobiet i mężczyzn. Podobnie jak w 1989 roku pojawił się temat praw reprodukcyjnych, zarówno $\mathrm{w}$ odniesieniu do zakazu aborcji (między innymi w nawiązaniu do filmu

${ }^{4}$ Był to jednocześnie jeden z pierwszych tematów analiz socjologicznych i politycznych, odnoszących się do kwestii płci w transformującej się Polsce. Por.: Mirosław Chałubiński (red.), Polityka i aborcja, Scholar, Warszawa 1994; Jacqueline Heinen, Anna Matuchniak-Krasuska, Aborcja w Polsce - kwadratura koła, przeł. Anna Matuchniak-Krasuska, Zbigniew Marcin Kowalewski, Polskie Towarzystwo Religioznawcze, Warszawa 1995.

5 Ten biblijny frazeologizm oznaczający ofiarę okupioną niezwykłym wyrzeczeniem w publicystyce prasowej zaczął być używany dla określenia renty, którą może otrzymywać wdowa po zmarłym mężu. Renta należy się kobiecie nie posiadającej dochodów, która skończyła w chwili śmierci małżonka 45 lat. Wypłacana jest dożywotnio od chwili ukończenia przez wdowę 50 lat. Nowa ustawa emerytalna przewidywała podwyższenie wieku, od którego wypłacanoby świadczenie do 60 roku życia. W wyniku protestów resort pracy wycofał się z planowanych zmian.

${ }^{6}$ „Becikowe” to potoczna nazwa jednorazowego zasiłku wypłacanego z tytułu urodzenia się dziecka. „Becikowe” było elementem polityki prorodzinnej zaproponowanej przez Ligę Polskich Rodzin. Jego wysokość wynosiła tysiąc złotych i, w początkowym okresie po wprowadzeniu w 2005 roku, obejmowało wszystkie żywe dzieci, niezależnie od wysokości dochodu rodziców. 
dokumentalnego Podziemne państwo kobiet [2009]), jak i dyskusji wokół projektu uregulowań prawnych zapłodnienia in vitro oraz przymusowej sterylizacji Wioletty Woźnej. Pojawiło się też zagadnienie udziału kobiet w polityce w kontekście projektu ustawy o parytetach na listach wyborczych oraz w ciałach decyzyjnych UE, a także problematyka polityki rodzinnej („becikowe”) i polityki społecznej odnoszącej się wprost lub pośrednio do kobiet (świadczeń dla wdów, podniesienia wieku emerytalnego oraz zrównania wieku emerytalnego kobiet i mężczyzn).

Tematykę kobiecą w obu analizowanych półroczach reprezentują więc aborcja, udział kobiet w polityce i kwestia pracy zawodowej kobiet. Kwestii aborcji - której zakazu w roku 1989 nawet nie rozważano hipotetycznie - w roku 2009 towarzyszy fakt naruszenia praw reprodukcyjnych kobiet; przykładem może tu być odmówienie legalnej aborcji Alicji Tysiąc, jak i sterylizacja (bez jej zgody) Wioletty Woźnej. Sprawy pracy zawodowej kobiet, zasygnalizowane w 1989 roku, w 2009 uzupełniają, wspomniane już, kwestie rent, emerytur i świadczeń rodzinnych. W tym samym roku lista poszerza się o tematy związane z aktywnością społeczno-polityczną kobiet. Przykładem może być Kongres Kobiet, któremu „GW” poświęciła dużo miejsca, angażując się również w patronat nad obywatelskim projektem ustawy o parytecie na listach wyborczych, postulowanym przez Kongres. Wcześniej „GW” inicjowała szereg akcji dotyczących kobiet: w 1994 była to akcja „Rodzić po ludzku", w 1999 - cykl artykułów zapoczątkowany tekstem Agnieszki Graff Patriarchat po seksmisji (w tym czasie rozwijał się dodatek „Wysokie Obcasy”), obecnie jest to kompania „Energia kobiet”. Zaangażowanie w inicjatywę na rzecz parytetów było chyba najbardziej równościową akcją „GW”, a przy tym najbliższą środowiskom kobiecym i feministycznym. Ani poprzednie „kobiece” obywatelskie projekty ustaw, jak ta o funduszu alimentacyjnym (2004), ani następne, jak inicjatywa „Tak dla Kobiet”, postulującą zniesienie zakazu aborcji (2011), nie zyskały podobnego zainteresowania ze strony „GW”, lub wręcz były przez nią przemilczane.

Badanie miało też na celu zbadanie proporcji kobiet wśród autorów tekstów zamieszczanych na pierwszej stronie i redaktorek poszczególnych wydań, jak również poszukiwanie ewentualnego związku między ich płcią a przedstawianiem samych kobiet oraz tematyki kobiecej i równościowej. W 1989 roku w stopce redakcyjnej „Gazety Wyborczej” znaleźć można było informację, że redakcja składa się z jednej kobiety i czterech mężczyzn, lub jednej kobiety i trzech mężczyzn, lub dwóch kobiet i trzech mężczyzn. Po podsumowaniu okazało się, że jeśli liczbę wszystkich wymienionych w stopce redakcyjnej potraktować jako 100 proc., kobiety stanowiły w tym czasie 22, a mężczyźni 78 proc. składu redakcji. Mężczyźni byli autorami lub współautorami 219 tekstów, które znalazły się na pierwszej stronie, 
a kobiety - 47, czyli 17 proc. Część owych tekstów dotyczyła problematyki kojarzonej z kobietami, jak służba zdrowia czy podwyżki cen żywności, lecz dziennikarki pisały też na tematy stereotypowo uważane za męskie, czyli o polityce i gospodarce (posiedzenia sejmu, obrady Obywatelskiego Klubu Parlamentarnego, formowania rządu, posiedzenia senackiej Komisji Gospodarki Narodowej, wizycie George’a Busha i konflikcie w Oświęcimiu).

W 2009 roku na pierwszej stronie widniała już informacja o redaktorze prowadzącym dany numer, więc uwzględniono to w dalszym badaniu. Analizie poddano także proporcje ilościowe autorów tekstów. W przebadanych 153 wydaniach redaktorami prowadzącymi byli częstej mężczyźni - 126 razy, rzadziej kobiety - 27 razy (17,65 proc.). W tych wydaniach gazety, których redaktorami prowadzącymi były kobiety rzadziej pojawiały się na pierwszej stronie kobiety, a nawet częściej były one nieobecne; niewielka próba nie pozwala na dalej idące wnioski o charakterze ilościowym. Wydaje się więc, że płeć autorki nie zwiększa prawdopodobieństwa przestawiania przez nią innych kobiet lub kobiecych tematów.

Tematyka tekstów, których autorkami były kobiety w 2009 roku to: parytety na listach wyborczych, korespondencja ze Strasburga, medycyna i służba zdrowia, ptasia grypa, prywatyzacja, deficyt budżetowy, wzrost PKB, kryzys rządowy, prawa człowieka, Czeczenki pobite w Polsce, sprawa ojca, który żył w kazirodczym związku z córką, sprawa Barbary Blidy, komisja ds. CBA, podwyżki cen, media i finanse publiczne, reforma emerytalna, edukacja i polityka. Jak widać, dziennikarki „GW” w 2009 roku (podobnie jak w 1989) zajmowały się zarówno tematyką tradycyjnie zarezerwowaną dla kobiet (służba zdrowia, oświata, polityka społeczna, emerytalna, podwyżki cen), jak i tematami postrzeganymi jako typowo męskie (polityka, gospodarka).

Ani w 1989, ani w 2009 roku nie udało się zaobserwować związku między płcią autorek i redaktorek a zawartością numeru. Procentowy udział autorek był znacznie wyższy niż udział kobiet w treściach, co dowodzi, że kobiety niekoniecznie częściej niż mężczyźni piszą o sprawach kobiet. Jednocześnie dziennikarki częściej poruszają tematykę zdrowia, polityki społecznej, polityki gospodarczej w jej codziennych przejawach (podwyżki cen czy kolejki), a także kobiet jako ofiar systemu. Tematy te niemal zupełnie nie są poruszane przez dziennikarzy-mężczyzn. Płeć redaktorów prowadzących odwrotnie koreluje z płcią newsów: w tych wydaniach z 2009 roku, w których redaktorami prowadzącymi były kobiety zawartość pierwszej strony dziennika rzadziej lub wcale dotyczyła kobiet.

Przedstawione badania mogą prowadzić do wniosku, że w omawianym okresie nie istniały zagadnienia dotyczące kobiet i ich problemów na tyle istotne, by stać się przedmiotem rozważań ogólnopolskich mediów informacyjnych. Tak też interpretowany jest najczęściej brak informacji na temat 
kobiet w „Gazecie Wyborczej”. Ze względu na to, że w 1989 roku nie było mediów kobiecych o charakterze informacyjnym, niemożliwym wydaje się dokonanie analizy porównawczej w sposób bezpośredni wykazującej mylność powyższego wniosku. Na rynku jednak pojawiły się wydawnictwa, które jednoznacznie podważają prawdziwość stwierdzenia o marginalnej roli kobiet w polskim społeczeństwie w tym okresie. Jako jedno z nich potraktować można Kronikę kobiet, która obejmuje również wydarzenia 1989 roku.

Kronika kobiet to jedno z cyklu publikacji Kronika... wydanych nakładem Chronik-Verlag7. Polska wersja jest tłumaczeniem niemieckiego oryginału, uzupełnionym o materiały dotyczące Polski i Polek. Ukazała się w 1993 roku, a badany okres reprezentowany jest na jednej stronie. Co interesujące, wymieniono tam aż jedenaście kobiet i tylko sześciu mężczyzn. Wśród wymienionych kobiet znalazły się: Teresa Dobielińska-Eliszewska, Olga Krzyżanowska, Zofia Kuratowska, Izabella Cywińska, Anna Radziwiłł, Krystyna Sienkiewicz, Małgorzata Niezabitowska i Barbara Labuda ${ }^{8}$, a także Raisa Orłowa-Kopielew ${ }^{9}$, Bette Davis ${ }^{10}$ i Trude Unruh ${ }^{11}$. Trzy z nich nie pojawiły się na pierwszych stronach „GW” $\mathrm{w}$ badanym okresie ${ }^{12}$. Jednocześnie autorzy Kroniki... komplementowali wysoki udział kobiet w nowo wybranym sejmie (zwanym później „kontraktowanym”) nieco na wyrost, bo chodziło o jedynie 13 proc., czyli znacznie mniej niż u schyłku PRL-u. Ograniczony materiału jaki zawiera Kronika kobiet nie upoważnia, jak wcześniej wspomniano, do przeprowadzenia porównań ilościowych.

Nieco inna sytuacja ma miejsce w przypadku roku 2009, kiedy rolę największego medium kobiecego o charakterze informacyjnym pełnił portal Feminoteka (www.feminoteka.pl). Nieliczne czasopisma feministyczne wydawane w tradycyjnej, papierowej formie były wtedy kwartalnikami lub półrocznikami i pełniły funkcję przede wszystkim publicystyczną, podczas gdy funkcję informacyjną spełniały media elektroniczne. Portal Feminoteka

7 Kronika kobiet, [oprac. całości zespół pod kier. Mariana B. Michalika; oprac. red. tekstów zespół tł. z niem., red. i korektorów pod kier. Marii Żmigrodzkiej-Wolskiej], Wydawnictwo „Kronika”, Warszawa 1993.

8 Pełniły one następujące funkcje w tym okresie: Teresa Dobielińska-Eliszewska wicemarszałek sejmu, Olga Krzyżanowska - członkini Prezydium Sejmu, Zofia Kuratowska - wicemarszałek senatu, Izabella Cywińska - minister kultury i sztuki, Anna Radziwiłł - wiceminister edukacji, Krystyna Sienkiewicz - wiceminister zdrowia, Małgorzta Niezabitowska - rzeczniczk prasowy rządu i Barbara Labuda - posłanka oraz przewodnicząca Parlamentarnego Koła Kobiet.

9 Zmarła pisarka radziecka.

${ }_{10}$ Zmarła aktorka amerykańska.

${ }^{11}$ Polityczka niemiecka, która została przewodniczącą założonej wówczas Partii Szarych.

${ }^{12}$ Były to: Anna Radziwiłł, Krystyna Sienkiewicz i Teresa Dobielińska-Eliszewska. 
powstał w 2004 roku $^{13}$, zaś fundacja o tej samej nazwie w $2005^{14}$. Inicjatorkami obu projektów były w dużym stopniu ówczesne pracownice Ośrodka Informacji Środowisk Kobiecych (OŚKa). OŚKa początkowo wydawała comiesięczne kalendarium, rozsyłane pocztą do różnych organizacji i indywidualnych prenumeratorek. Jego swoistą kontynuacją stał się portal Feminoteka ${ }^{15}$.

Dla potrzeb badania analizie poddana została część informacyjna portalu, czyli treści, które znajdując w głównej części strony, pełnią podobną rolę, jak strona tytułowa w gazecie. Pominięto natomiast zapowiedzi artykułów o charakterze publicystycznym oraz informator o imprezach zamieszczony po prawej stronie witryny internetowej. Podobnie jak w przypadku „GW” porównane zostały ilościowe proporcje występowania kobiet i mężczyzn, a także sposób przedstawiania kobiet. Trudno było porównać ilustracje, bo tych - poza logami organizacji (jak Fundacja MaMa) i zdjęciami autorek lub bohaterek newsów (jak Magdalena Środa) - na witrynie niemal nie ma. Być może metodologicznie bardziej poprawne byłoby porównanie zawartości portali internetowych Feminoteka i „GW”, lecz jedynie ten pierwszy pozostał dostępny do badania; zawartość stron www.gazeta.pl czy www.wyborcza.pl nie zachowała się.

Jako że portal Feminoteka ma charakter kobiecy i feministyczny, wyniki analizy ilościowej nie są zaskakujące: kobiety stanowią zdecydowaną większość bohaterów newsów, a problematyka równościowa zajmuje kluczowe miejsce. Analizie poddano 454 newsy, w których występowało 71,3 proc. kobiet w treści wiadomości, 79,4 proc. $\mathrm{w}$ tytułach i podtytułach liczonych razem i aż 81,8 proc. kobiet w tytułach głównych (bez podtytułów). Jeśli chodzi o tematykę newsów, w drugim półroczu 2009 roku przedstawiała się ona następująco:

- przemoc wobec kobiet - zbiorowy portret ofiar przemocy, przemoc domowa, przestępstwa seksualne (molestowanie w pracy, gwałty, gwałty wojenne, handel kobietami);

- dyskryminacja - seksistowskie żarty, dyskryminacja płacowa (w sektorze bankowym, kobiet-pastorów w USA), dyskryminacja ojców, stereotypy płci;

- dyskursy antyfeministyczne, mizoginistyczne i homofoniczne (np. wypowiedź określająca feministki jako niespełnione kobiety, „eutanaziści” Tomasza Terlikowskiego, propaganda neonazistowska, ataki na osoby i inicjatywy związane ze środowiskiem LGBT);

${ }^{13} \mathrm{Na}$ taką datę wskazuje zapis na startowej stronie portalu; dostępne przez: http:// www.feminoteka.pl/news.php?rowstart $=5670$ (31.05.2012).

14 Ibidem.

15 OŚKa wydawała też czasopismo, którego następcą jest publicystyczna, nie poddana tu analizie, część portalu. 
- równość kobiet i mężczyzn - polityka równych szans, manifest równych szans kobiet i mężczyzn Polskiej Konfederacji Pracodawców Prywatnych Lewiatan, powołanie rzecznika ds. kobiet, krytyka polskiej polityki równościowej, podział ról w rodzinie;

- żeńskie końcówki - akcja Fundacji Feminoteka na rzecz ich używania i protesty przeciwniczek;

- kobiety w polityce - parytety na listach wyborczych, udział kobiet w polityce;

- feminizm - audycja Jestem feminista w radiu publicznym;

- inicjatywy i wydarzenia - manify, Kongres Kobiet, powstanie Śląskiej Przedwyborczej Koalicji Kobiet, sieci kół Kampanii Przeciw Homofobii;

- prawa reprodukcyjne - odmowy badań prenatalnych, zakaz aborcji, indyjska polityka regulacji urodzeń, zapłodnienie in vitro, zawetowanie przez Polskę deklaracji ONZ o dostępie do zdrowia reprodukcyjnego, legalizacja pigułki aborcyjnej we Włoszech, liberalizacja prawa aborcyjnego w Hiszpanii, zakończenie działalności Kobiet na Falach, edukacja seksualna;

- zdrowie kobiet i dziewczą - „amazonki” (kobiety po operacji amputacji piersi), akcje „Rodzić po ludzku” i „Przyjazny ginekolog”, śmiertelność noworodków, uczennice w ciąży, projekt obowiązkowej cytologii i mammografii;

- „herstoria” (przywracanie zapomnianej historii kobiet) - Krakowski Szlak Kobiet, kobiety a pamięć Holocaustu, kobiety w Auschwitz, procesy czarownic;

- $\quad$ sytuacja kobiet w różnych krajach (np. Afganistan, Arabia Saudyjska, Malezja) - polityka, prawa pracownicze, zdrowie kobiet, prawa reprodukcyjne;

- protesty zbiorowe i akcje poparcia (np. na rzecz i przeciwko projektowi ustawy o parytetach na listach wyborczych, za i przeciw wystawom antyaborcyjnym);

- listy otwarte i apele (np. list profesor PAN piętnujący liczbę kobiet wśród kandydatów na członków-korespondentów tej organizacji, projekt listu otwartego organizacji kobiecych w sprawie odwołania minister Elżbiety Radziszewskiej, „wdowi grosz”);

- religia - lekcje religii w szkole, wliczanie oceny z religii do średniej, protesty;

- polityka społeczna - ubóstwo na świecie, bieda i walka z wykluczeniem społecznym kobiet;

- polityka rodzinna - nowelizacja kodeksu rodzinnego, wprowadzenie urlopów ojcowskich, ograniczenie praw wdów do zabezpieczenia rentowego, składki na ZUS podczas urlopie wychowawczym, urlopy 
macierzyńskie, rodzicielskie, opieka nad dziećmi, opłaty za przedszkola, brak miejsc w przedszkolach, przemoc wobec dzieci, alimenty, „becikowe”;

- prawa pracownicze w odniesieniu do kobiet (np. raport Clean Clothes Campaign o sytuacji pracownic przemysłu odzieżowego, zwolnienia w fabrykach Triumpha w Tajlandii i na Filipinach, protest pielęgniarek w Radomiu, zwolnienie pielęgniarek-aktywistek związkowych w Łodzi i sprzątaczek w Lublinie, zagrożone zwolnieniem z pracy nauczycielki w ciąży);

- nominacje i nagrody dla kobiet - literackie (np. dla Ingi Iwasiów, Bożeny Keff [wcześniej Umińskiej]), polityczne i społeczne (np. dla Aung San Suu Kyi na Ambasadora Sumienia, „społeczny Nobel” dla Katarzyny Batko-Tołuć);

- kobiety w kościele - kobiety a Kościół katolicki, kobiety a kościoły, rola Wandy Półtawskiej, kapłaństwo kobiet, lesbijki w kościołach;

- kobiety w wojsku;

- kobiety na uczelniach - sytuacja kobiet na uczelniach technicznych, molestowanie, apel o powołanie na uczelniach pełnomocnika ds. równości;

- kobiety w mediach (np. program telewizyjny Babiląd z udziałem kobiet w roli ekspertek);

- problemy seniorek;

- życiowe priorytety kobiet;

- zagadnienia dotyczące osób i środowisk LGBT (np. litewska ustawa zakazująca mówienia o osobach homoseksualnych w szkołach, szkolenie z tolerancji dla policji, potrzeba ustawy o związkach partnerskich, książeczka dla dzieci o parze pingwinów-gejów, pamięć o historii osób transpłciowych, adopcja przez pary jednopłciowe, śluby gejów i lesbijek w Szwecji;

- konferencje, wykłady, debaty, seminaria, pokazy filmów;

- publikacje, książki, np. dla dzieci o miesiączce, i czasopisma: queerowy numer „Ha!artu”, nowy numer „Repliki”;

- zielony styl życia;

- wyrok na rodziców - zabójców pięciorga nowonarodzonych dzieci;

- kastracja pedofilów.

Przedstawione wyliczenie jednoznacznie dowodzi znacznej obecności kobiet w życiu społeczno-politycznym w omawianym okresie. Na coraz większą świadomość ich znaczenia wskazuje nawet analiza porównawcza pierwszych stron „Gazety Wyborczej” z lat 1989 i 2009 (patrz: tab. 1). Ocena tej zmiany ulega jednak weryfikacji, gdy zestawione zostaną dane dotyczące pierwszych stron „GW” z 2009 roku z danymi zamieszczonymi w tym samym 
okresie na portalu Feminoteka (zachowując świadomość stricte kobiecego charakteru tego medium).

Zestawienie treści pod względem jakościowym ujawnia pomniejszanie roli kobiet w obszarze społeczno-polityczno-kulturowym Polski. Na pierwszą stronę „GW” ma szansę trafić laureatka wyborów piękności, ale nie nagród naukowych. Tytuły newsów Feminoteki wymieniają o wiele więcej noblistek niż tytuły „GW”. Kobiety przedstawiane są tam nie tylko w roli nagradzanych, ale także inicjatorek i organizatorek ważnych wydarzeń. Ponadto, przykładowo noblistki to nie tylko tegoroczne laureatki, portal przypomina je nie tylko wtedy, gdy skupiają uwagę mediów. Feminoteka w tytułach wymienia kobiety aktywne na polu działalności społecznej, a kobiety zaangażowane $\mathrm{w}$ ruch feministyczny nazywane są feministkami. W obu mediach występuje podobna liczba kobiet ze świata polityki, ale Feminoteka pisze zarówno o polityczkach pełniących wysokie funkcje, jak również polityczkach opozycyjnych; odnotowuje powoływanie kolejnych kobiet na polityczne urzędy i, szerzej niż „GW”, informuje o tym, co dzieje się w odległych zakątkach świata. Poświęca swe elektroniczne łamy autorkom i sygnatariuszkom licznych listów protestacyjnych lub poparcia. Niezwykle rzadko pisze przy tym o kobietach jako żonach swych mężów i w porównaniu do „GW” częściej wymienia kobiety jako recenzentki, redaktorki, autorki, twórczynie i wykładowczynie. Na Feminotece niejednokrotnie w kontekście religii mowa o innych niż katolicka religiach. Pojawiają się duchowne, a nawet biskupki protestanckie, choć także katolickie zakonnice z USA, kwestionujące autorytet Watykanu i zajmujące feministyczne stanowiska. Portal przełamuje tabu heteronormatywności, poświęcając wiele miejsca osobom nieheteroseksualnym.

Przeprowadzona analiza pokazuje marginalizowanie kobiet i problematyki kobiecej przez media mainstreamowe (bo zjawisko to nie dotyczy wyłącznie wybranej do badania „Gazety Wyborczej”, uważanej za przychylną dla problematyki równościowej i angażującej się niekiedy w akcje z nią związane). Wprawdzie nastąpił ilościowy wzrost udziału kobiet i zmniejszenie dysproporcji między płciami na łamach „GW”, to daleko jednak do ilościowego zrównania kobiet i mężczyzn. Okazuje się też, że zmniejszaniu dysproporcji ilościowej reprezentacji kobiet i mężczyzn nie towarzyszy zmiana jakościowa. Choć rozszerza się wachlarz ról, w jakich kobiety są prezentowane, nadal dominują role marginalne i pozbawione sprawczości. Polityczki są równie często opisywane, co żony polityków, a na pierwszą stronę łatwiej trafić ofierze przemocy lub bohaterce skandalu niż kobiecie zasłużonej na polu nauki, sztuki czy nawet biznesu. O tym, jak wiele działań kobiet nie dociera do czytelników mediów głównonurtowych, świadczy analiza Feminoteki. Zawartość portalu jest też pozytywnym przykładem, który powinien posłużyć medialnym decydentom do zmian wizerunku kobiet. 


\section{BIBLIOGRAFIA}

Chałubiński Mirosław (red.), Polityka i aborcja, Scholar, Warszawa 1994.

Desperak Izabela, Pteć w kampaniach wyborczych 2000-2011, „Władza Sądzenia” 2013, $\mathrm{nr}$ 1; dostępne przez: http://wladzasadzenia.pl/2012/1/o5-plec-w-kampaniach-wyborczych.pdf (17.03.2013).

Heinen Jacqueline, Anna Matuchniak-Krasuska, Aborcja $w$ Polsce - kwadratura koła, przeł. Anna Matuchniak-Krasuska, Zbigniew Marcin Kowalewski, Polskie Towarzystwo Religioznawcze, Warszawa 1995.

Kronika kobiet, [oprac. całości zespół pod kier. Mariana B. Michalika; oprac. red. tekstów zespół tł. z niem., red. i korektorów pod kier. Marii Żmigrodzkiej-Wolskiej], Wydawnictwo „Kronika”, Warszawa 1993.

Penn Shana, Podziemie kobiet, przeł. Hanna Jankowska, Rosner i Wspólnicy, Warszawa 2003. 